\title{
Culture of Meloidogyne hapla and M. javanica on Several Plant Roots Genetically Transformed by Agrobacterium rhizogenes
}

\author{
Hiroshi Adachi*, Takashi NARABU** and Yoji Momota***
}

\begin{abstract}
Reproduction of Meloidogyne hapla and M. javanica was compared on Agrobacterium rhizogenes-transformed roots from several plants under monoxenic conditions. Meloidogyne hapla normally matured and laid eggs on transformed roots of tomato plants that were susceptible (Lycopersicon esculentum MiLl. cv. Farstmore) or resistant (cv. Momotaro) to the nematode. Meloidogyne javanica normally matured and laid eggs on tomato (L. esculentum MiLl. cv. Fastmore) and eggplant (Solanum melongena L.), but not on resistant tomato plants. The developmental zero degrees were $6.8^{\circ} \mathrm{C}$ for $M$. hapla and $10.1^{\circ} \mathrm{C}$ for $M$. javanica. The day-degrees for the onset of oviposition and for the completion of one generation after inoculation with 2nd-stage juveniles were 435 and 692 for $M$. hapla, and 378 and 566 for $M$. javanica, respectively. A slight negative temperature-dependency was detected in body length, tail length and a-value of juveniles of M. hapla and M. javanica. Jpn. J. Nematol. 23: 63-70 (1993).

Key words: developmental rate, hairy root, root-knot nematode, temperature, transformed root
\end{abstract}

Recently, plant roots genetically transformed by Agrobacterium rhizogenes, the casual agent of hairy root diseases, have been used for research on the physiology and behavior of root-knot nematodes under sterile conditions(12). ADACHI et al.(1) demonstrated that there were no significant differences between the ordinary oriental-melon (Cucumis melo L.) roots and the transformed ones in day-degrees for both the onset of oviposition and completion of one generation, developmental zero degree, and body dimensions of pre-parasitic Meloidogyne incognita 2ndstage juveniles. Transformed roots have not been used to study the influence of the temperature on the development and body dimensions of pre-parasitic 2nd-stage juveniles in different rootknot nematode species.

This paper reports the reproduction of the northern root-knot nematode, $M$. hapla, and the Javanese root-knot nematode, $M$. javanica, on transformed roots. Various plant species were employed for determining developmental zero degree, day-degree for the completion of one generation, and body dimensions of pre-parasitic 2nd-stage juveniles.

\section{MATERIALS AND METHODS}

\section{Genetic transformation of plant roots}

${ }^{*}$ Biological Science Research Center, Lion Corporation, Tajima, Odawara, Kanagawa, 256 Japan.

** National Agriculture Research Center, Kannondai, Tsukuba, Ibaraki, 305 Japan.

*** Hokuriku National Agricultural Experiment Station, 1-2-1 Inada, Joetu, Niigata, 943-01 Japan. 
Seeds of tomato (Lycopersicon esuculentum MiLL. cv. Fastmore [nematode-susceptible genotype] and cv. Momotaro [nematode-resistant genotype*]), Ladino clover (Trifolium repens L. race giganteum) and eggplant (Solanum melongena L. cv. Nakate) were surface-sterilized with a $0.05 \%$ sodium hypochlorite solution for 15 min. After being rinsed several times with sterile distilled water, the seeds were transferred to glass tubes containing Woody Plant Medium (4) (WP), supplemented with $3 \%$ sucrose and $0.2 \%$ gellan gum (Scott Laboratories, Inc., California, U.S.A.), adjusted to $\mathrm{pH} 5.5$. The glass tubes were incubated at $25^{\circ} \mathrm{C}$, under $16 \mathrm{hrs}$ illumination. For the inoculation experiments, 2 weeks old seedlings were used.

The leaves and cotyledons were cut into pieces of approximately $0.2 \mathrm{~cm}^{2}$ and exposed to a 1:1000 diluted solution of an overnight culture of Agrobacterium rhizogenes (MAFF 03-01724) in YEB medium. After 30 minutes, the segments were transferred to WP medium solidified with $1 \%$ agar (Wako Pure Chemical Industries, Ltd., Tokyo, Japan) containing $0.5 \%$ cefotaxime sodium (Hoechst Japan, Ltd., Tokyo, Japan) in order to suppress bacterial growth. Developing roots from the pieces were subcultured on the fresh WP medium 3 times at 10-day intervals. The vigorously growing hairy roots free from $A$. rhizogenes were selected from young root tips. The transformed character of the hairy roots was tested for the presence of mikimopin, according to TANAKA et al.(9).

\section{Culture of nematodes on transformed roots}

The nematodes used in this study were $M$. hapla and $M$. javanica that originated from infected peanuts, Arachis hypogaea L., in Yachimata, Chiba Prefecture, and from infected konjak, Amorphoaphalus konjac C. КосH, in Fukushima, Fukushima Prefecture, respectively. Each population was maintained on tomato plants (L. esculentum MiLl. cv. Kyoryoku-beiju) grown in a glasshouse from a single egg mass.

Egg masses collected from tomato roots were placed in water at $25^{\circ} \mathrm{C}$ and juveniles hatched within $48 \mathrm{hrs}$ were used. Juveniles were surface-sterilized with $420 \mu \mathrm{g} / \mathrm{ml}$ methoxyethylmercuric chloride for 20 min., then treated with $0.5 \%$ streptomycin sulfate (Wako Pure Chemical Industries, Ltd., Tokyo, Japan) for $20 \mathrm{~min}$, and finally washed three times with sterilized water. Eighty juveniles were inoculated onto a transformed root tip (approximately $5 \mathrm{~cm}$ long) with 200 $\mu 1$ sterilized water in a petri dish (9 cm diameter) containing $30 \mathrm{ml}$ of $\mathrm{RM}(2)$ medium.

Nematodes were cultured on transformed roots of tomato (cv. Fastmore) at constant temperatures of $20,25,27$ and $30( \pm 0.1){ }^{\circ} \mathrm{C}$. Time required for oviposition and hatching of embryos for each nematode species was investigated. The experiment was performed three times for each temperature.

\section{Measurements of juveniles}

Hatched 2nd-stage juveniles from tomato transformed roots at different temperatures were killed by gentle heating $\left(60{ }^{\circ} \mathrm{C}, 1 \mathrm{~min}\right.$.) and subsequently fixed by TAF fixative. The juveniles were mounted in the same fixative solution and the body length, maximum body width, body width at anus and tail length were mesured to yield the a-value, $c^{-}$-value and $\mathrm{c}^{\prime}$-value using 30 50 juveniles for each treatment.

\footnotetext{
*Resistant to M. incognita, M. javanica, and M. arenaria, but not to M. hapla.
} 
Table 1. Reproduction of Meloidogyne hapla and M. javanica on genetically transformed roots of several plants by Agrobacterium rhizogenes.

\begin{tabular}{|c|c|c|c|c|c|c|}
\hline \multirow[b]{2}{*}{ Host } & \multicolumn{3}{|c|}{ M. hapla } & \multicolumn{3}{|c|}{ M. javanica } \\
\hline & $\begin{array}{l}\text { Days re- } \\
\text { quired for } \\
\text { hatching }\end{array}$ & $\begin{array}{l}\text { Fertile } \\
\text { females/ } \\
\text { petri dish }\end{array}$ & $\begin{array}{l}\text { Number of } \\
\text { eggs/egg } \\
\text { mass }\end{array}$ & $\begin{array}{l}\text { Days re- } \\
\text { quired for } \\
\text { hatching }\end{array}$ & $\begin{array}{l}\text { Fertile } \\
\text { females/ } \\
\text { petri dish }\end{array}$ & $\begin{array}{l}\text { Number of } \\
\text { eggs/egg } \\
\text { mass }\end{array}$ \\
\hline $\begin{array}{l}\text { Tomato } \\
\text { (cv. Momotaro**) }\end{array}$ & $38 \pm 5$ & $27 \pm 10$ & $849 \pm 163$ & $-^{*}$ & 0 & - \\
\hline $\begin{array}{l}\text { Tomato } \\
(\mathrm{cv} . \text { Fastmore } \\
\text { ***) }\end{array}$ & $38 \pm 1$ & $25 \pm 9$ & $909 \pm 123$ & $38 \pm 1$ & $16 \pm 3$ & $880 \pm 124$ \\
\hline Eggplant & $42 \pm 1$ & $2 \pm 1$ & $362 \pm 81$ & $39 \pm 1$ & $15 \pm 10$ & $971 \pm 186$ \\
\hline Ladino clover & $39 \pm 2$ & $26 \pm 8$ & $625 \pm 92$ & $39 \pm 2$ & $26 \pm 9$ & $442 \pm 77$ \\
\hline
\end{tabular}

Inoculum level was $82 \pm 3$ juveniles per petri dish at $25^{\circ} \mathrm{C}$. Values are means of three replications \pm standard deviation.

* Gall formation and oviposition were not observed.

** Resistant genotype to Meloidogyne spp. except for M. hapla.

*** Susceptible genotype to Meloidogyne spp.

\section{RESULTS}

\section{Reproduction of nematodes on transformed roots}

Reproduction data of two nematode species on transformed roots are presented in Table 1.

Meloidogyne hapla: At the penetration site of $M$. hapla, gall formation of roots began 4 days after inoculation, showing characteristic radial ramification of secondary roots (Fig. 1). This nematode grew on hairy roots of all tested plants and reached the adult female stage with egg mass. Days required for the completion of one generation from inoculated 2nd-stage juvenile to newly hatched juvenile were 38,42 , and 39 on tomato (cv. Momotaro and cv. Fastmore), eggplant, and Ladino clover at $25^{\circ} \mathrm{C}$, respectively. On eggplant, numbers of both adult females and eggs were significantly smaller $(p<0.05)$ than those on other plants. The largest number of laid-eggs was obtained from tomato (cv. Momotaro and cv. Fastmore).

Meloidogyne javanica: Neither gall formation nor oviposition was observed on tomato (cv. Momotaro).

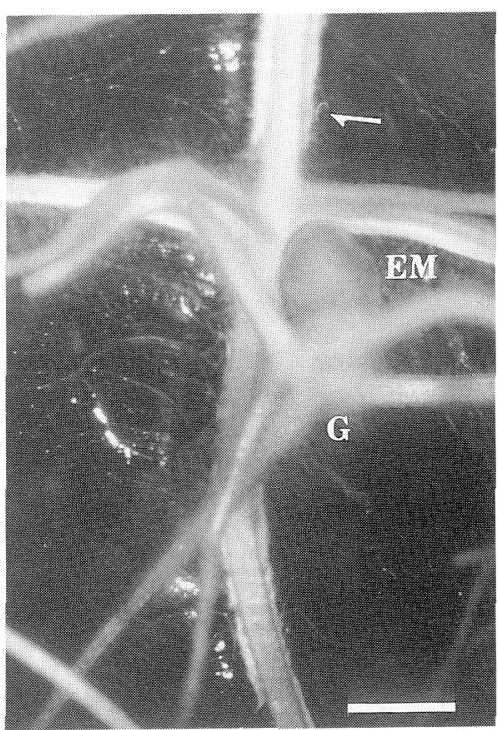

Fig. 1. Gall (G), egg mass (EM) and hatched juveniles (arrow) of Meloidogyne hapla on the transformed roots of tomato, Lycopersicon esculentum Mill.cv. Fastmore 40 days after nematode inoculation at $25^{\circ} \mathrm{C}$. Scale bar $=1 \mathrm{~mm}$. On transformed roots other than tomato (cv. Momotaro), gall formation and further development up to the adult female stage with egg mass were observed along with the enlargement of the penetration sites 4 days after inoculation. Days required for the completion of one generation from inoculated 2nd-stage juvenile to newly hatched juvenile were 38,39 and 39 on tomato (cv. Fastmore), eggplant, and Ladino clover, respectively. Mature adult females were found in the transformed roots of these three plants and a larger number of eggs was laid on tomato (cv. 
Table 2. Effect of temperature on the development of Meloidogyne hapla and M. javanica on the transformed root culture of tomato, Lycopersicon esculentum MiLl. cv. Fastmore.

\begin{tabular}{|c|c|c|c|c|c|c|}
\hline \multirow[b]{2}{*}{$\begin{array}{c}\text { Temperature } \\
\left({ }^{\circ} \mathrm{C}\right)\end{array}$} & \multicolumn{3}{|c|}{ M. hapla } & \multicolumn{3}{|c|}{ M. javanica } \\
\hline & $\begin{array}{l}\text { Days } \\
\text { required for } \\
\text { hatching }\end{array}$ & $\begin{array}{l}\text { Egg masses/ } \\
\text { petri dish }\end{array}$ & $\begin{array}{l}\text { Number of } \\
\text { eggs/egg } \\
\text { mass }\end{array}$ & $\begin{array}{l}\text { Days } \\
\text { required for } \\
\text { hatching }\end{array}$ & $\begin{array}{l}\text { Egg masses/ } \\
\text { petri dish }\end{array}$ & $\begin{array}{l}\text { Number of } \\
\text { eggs/egg } \\
\text { mass }\end{array}$ \\
\hline 20 & $50 \pm 5 a^{* *}$ & $23 \pm 10 a$ & $706 \pm 151 a$ & $49 \pm 1 a$ & $23 \pm 12 a$ & $951 \pm 181 \mathrm{ab}$ \\
\hline 25 & $38 \pm 3 b$ & $26 \pm 9 a$ & $969 \pm 123 a$ & $38 \pm 2 b$ & $13 \pm 3 b$ & $780 \pm 124 a$ \\
\hline 27 & $35 \pm 1 b$ & $21 \pm 5 a$ & $753 \pm 224 a$ & $31 \pm 3 c$ & $16 \pm 2 \mathrm{ab}$ & $957 \pm 383 a b$ \\
\hline 30 & $44 \pm 2 \mathrm{a}$ & $5 \pm 2 b$ & $256 \pm 78 b$ & $28 \pm 3 c$ & $20 \pm 2 a$ & $1023 \pm 89 b$ \\
\hline
\end{tabular}

Inoculum level was $82 \pm 3$ juveniles per petri dish. Values are means of three replications \pm standard deviation.

* $25^{\circ} \mathrm{C}$ for five days after inoculation.

** Values followed by the same letter are not significantly different $(p=0.05)$ according to Student's $t$-test.

Fastmore) and eggplant than on Ladino clover $(p<0.05)$.

2. Effects of temperature on life cycle of the nematodes

The duration of one generation in $M$. hapla was shortened when the temperature rose in the range of $20-27^{\circ} \mathrm{C}$, though it was lengthened at $30^{\circ} \mathrm{C}$. Meloidogyne javanica required fewer days for completing one generation when the temperature rose within the range of $20-30^{\circ} \mathrm{C}$ (Table 2 ). The number of adult females and eggs per female in $M$. hapla apparently decreased at $30{ }^{\circ} \mathrm{C}$, in contrast to $M$. javanica (Table 2).

Linear correlations were obtained between the developmental rate (reciprocal of the number of days required from initiation of culture to juvenile hatching of the next generation) and the incubation temperature within the range of $20-27^{\circ} \mathrm{C}$ and $20-30^{\circ} \mathrm{C}$ for $M$. hapla and M. javanica, respectively (Fig. 2). These correlations were represented by the regression equations $Y=$

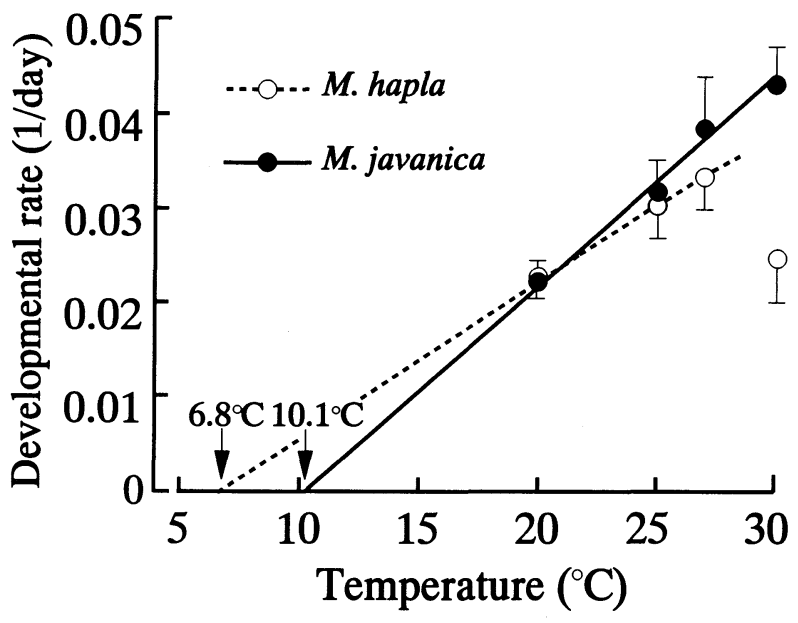

Fig. 2. Relationship between the temperature and developmental rate (reciprocal of number of days from inoculation with pre-parasitic 2nd-stage juveniles to newly hatched ones of the next generation).

Meloidogyne hapla $(\bigcirc), M$. javanica $(\bigcirc)$. The values are means \pm S.E. of three replications. The regression equation ; $Y=-0.0109+0.0016 X(r=$ $0.95)$ for M. hapla; $Y=-0.0233+0.0023 X(r=0.96)$ for $M$. javanica. 
Table 3. Developmental parameters of Meloidogyne hapla and M. javanica on the transformed roots of tomato, Lycopersicon esculentum MiLl. cv. Fastmore.

\begin{tabular}{lccc}
\hline \multicolumn{1}{c}{ Items } & M. hapla & M. javanica & M. incognita* \\
\hline Developmental zero $\left({ }^{\circ} \mathrm{C}\right)$ & 6.8 & 10.1 & 10.9 \\
Day-degree for oviposition & 435 & 378 & 296 \\
Day-degree for hatching & 692 & 566 & 473 \\
\hline
\end{tabular}

* Adachi et al. (1)

Table 4. Meloidogyne hapla 2nd-stage juveniles reproduced on the transformed roots of tomato, Lycopersicon esculentum Mill. cv. Fastmore at various temperatures.

\begin{tabular}{ccccccc}
\hline $\begin{array}{c}\text { Temperature } \\
\left({ }^{\circ} \mathrm{C}\right)\end{array}$ & $\begin{array}{c}\text { Number of } \\
\text { juveniles } \\
\text { examined }\end{array}$ & $\begin{array}{c}\text { Body length } \\
(\mathrm{A}) \\
(\mu \mathrm{m})\end{array}$ & $\begin{array}{c}\text { A/maximum } \\
\text { boby width } \\
(\mathrm{a})\end{array}$ & $\begin{array}{c}\text { Tail length } \\
(\mathrm{B}) \\
(\mu \mathrm{m})\end{array}$ & $\begin{array}{c}\mathrm{A} / \mathrm{B} \\
(\mathrm{c})\end{array}$ & $\begin{array}{c}\mathrm{B} / \mathrm{body} \\
\text { width at } \\
\text { anus }\left(\mathrm{c}^{\prime}\right)\end{array}$ \\
\hline 20 & 34 & $414.0 \pm 15.7$ & $27.4 \pm 1.6$ & $54.9 \pm 3.7$ & $7.6 \pm 0.4$ & $5.1 \pm 0.3$ \\
25 & 37 & $402.5 \pm 13.2$ & $26.7 \pm 1.4$ & $53.0 \pm 3.2$ & $7.6 \pm 0.3$ & $4.9 \pm 0.3$ \\
27 & 32 & $398.1 \pm 14.7$ & $25.3 \pm 1.6$ & $50.8 \pm 3.1$ & $7.8 \pm 0.4$ & $4.7 \pm 0.3$ \\
30 & 32 & $391.5 \pm 13.2$ & $24.9 \pm 1.5$ & $51.0 \pm 2.7$ & $7.6 \pm 0.4$ & $5.0 \pm 0.4$ \\
\hline $\begin{array}{c}\text { Correlation } \\
\text { coefficient }\end{array}$ & & $r=-0.48^{* * *}$ & $r=-0.46^{* * *}$ & $r=-0.42^{* * *}$ & $r=0.20^{\text {ns }}$ & $r=-0.21^{\text {ns }}$ \\
\hline
\end{tabular}

Values are means \pm standard deviation.

$* * *$ : Significant at $0.1 \%$ level, ns: Non-significant.

$-0.0109+0.0016 X(r=0.95)$ and $Y=-0.0233+0.0023 X(r=0.96)$, respectively. Based on these equations, the developmental zero degrees were calculated to be $6.8^{\circ} \mathrm{C}$ for $M$. hapla and $10.1^{\circ} \mathrm{C}$ for M. javanica (Fig. 2, Table 3). By using these values of developmental zero degrees as starting points, the total temperature required until the onset of oviposition or onset of hatching of juveniles was expressed for each total effective temperature $(K)$ by the following equation:

$K=(V-A) \times T+(25-A) \times 5$

where $V=$ incubation temperature

$A=$ developmental zero degree

$T=$ days until the onset of oviposition or juvenile hatching from the inoculation period, including 5 days for penetration at $25^{\circ} \mathrm{C}$.

Table 5. Meloidogyne javanica 2nd-stage juveniles reproduced on the transformed roots of tomato, Lycopersicon esculentum Mill. cv. Fastmore at various temperatures.

\begin{tabular}{ccccccc}
\hline $\begin{array}{c}\text { Temperature } \\
\left({ }^{\circ} \mathrm{C}\right)\end{array}$ & $\begin{array}{c}\text { Number of } \\
\text { juveniles } \\
\text { examined }\end{array}$ & $\begin{array}{c}\text { Body length } \\
(\mathrm{A}) \\
(\mu \mathrm{m})\end{array}$ & $\begin{array}{c}\mathrm{A} / \text { maximum } \\
\text { body width } \\
(\mathrm{a})\end{array}$ & $\begin{array}{c}\text { Tail length } \\
(\mathrm{B}) \\
(\mu \mathrm{m})\end{array}$ & $\begin{array}{c}\mathrm{A} / \mathrm{B} \\
(\mathrm{c})\end{array}$ & $\begin{array}{c}\mathrm{B} / \text { body } \\
\text { width at } \\
\text { anus }\left(\mathrm{c}^{\prime}\right)\end{array}$ \\
\hline 20 & 56 & $417.8 \pm 14.7$ & $27.9 \pm 1.2$ & $51.5 \pm 2.1$ & $8.2 \pm 0.2$ & $4.8 \pm 0.3$ \\
25 & 45 & $404.7 \pm 16.1$ & $27.6 \pm 1.4$ & $47.5 \pm 2.7$ & $8.5 \pm 0.3$ & $4.7 \pm 0.3$ \\
27 & 44 & $380.9 \pm 10.6$ & $25.9 \pm 1.4$ & $44.6 \pm 2.1$ & $8.5 \pm 0.3$ & $4.5 \pm 0.3$ \\
30 & 30 & $367.5 \pm 18.9$ & $24.5 \pm 1.7$ & $47.6 \pm 4.4$ & $8.1 \pm 0.5$ & $4.7 \pm 0.5$ \\
\hline $\begin{array}{l}\text { Correlation } \\
\text { coefficient }\end{array}$ & & $r=-0.67^{* * *}$ & $r=-0.41^{* * *}$ & $r=-0.52^{* * *}$ & $r=0.12^{\text {ns }}$ & $r=-0.30^{\text {ns }}$ \\
\hline
\end{tabular}

Values are means \pm standard deviation.

***: Significant at $0.1 \%$ level, ns: Non-significant. 
The total effective temperatures for the onset of oviposition and for hatching were 435 and 692 day-degrees, respectively, in M. hapla. The corresponding values for M. javanica were 378 and 566 day-degrees (Table 3).

\section{Measurements of body size of second-stage juveniles}

Tables 4 and 5 show the measurements of the body size of newly hatched 2nd-stage juveniles at each temperature in $M$. hapla and $M$. javanica, respectively. Significant negative correlations between body sizes and temperatures were obtained based on body length, a-value, and tail length for both nematode species. However, no temperature-dependency was observed for the c-value, $\mathrm{c}^{\prime}$-value, body width at anus and maximum body width.

\section{DISCUSSION}

Meloidogyne hapla formed galls on transformed roots of all tested plants and produced egg masses in the medium, while gall formation and oviposition by $M$. javanica were observed on three transformed roots except for tomato (cv. Momotaro). The emergence of juveniles in the culture medium occurred within 14 days after oviposition. It was possible to transfer the newly hatched juveniles to fresh transformed roots. These results confirmed that the transformed roots induced by $A$. rhizogenes can be employed for hosts of the two nematode species.

The number of fertile females per plate and eggs produced on transformed roots by one female varied with the plants. The number of fertile females was the largest on tomato and Ladino clover for $M$. hapla, and Ladino clover for $M$. javanica. However, the number of eggs produced by one female on Ladino clover decreased remarkably in $M$. javanica. The number of eggs per egg mass was the largest on tomato (cv. Momotaro) for M. hapla, while on tomato (cv. Fastmore) and eggplant for M. javanica.

On tomato cultivar resistant to root-knot nematodes (cv. Momotaro), M. javanica failed to form galls or lay eggs. In contrast to $M$. javanica, $M$. hapla propagated itself on the resistant cultivar at the same level as that on the susceptible cultivar, indicating that genetic transformation of tomato roots through $A$. rhizogenes did not alter the susceptibility to M. hapla (6) while the resistance to $M$. javanica was maintained.

VRAIN et al.(13) estimated the developmental zero degrees of $M$. hapla at $8.8^{\circ} \mathrm{C}$ on white clover cultivated in pot, and Milne \& Duplessis (5) obtained a value of $7.5^{\circ} \mathrm{C}$ for M. javanica on tobacco cultivated in the field. Since the cultivation and climatic conditions were different in the two reports, it is difficult to compare literally the developmental zero degrees and total effective temperature between the two nematodes. In the present study, therefore, we cultured $M$. hapla and $M$. javanica under the same conditions and estimated the value of developmental zero degree to be $6.8^{\circ} \mathrm{C}$ and $10.1^{\circ} \mathrm{C}$, respectively.

The total effective temperatures required for oviposition and for the completion of one generation from the pre-parasitic 2nd-stage juvenile to the onset of egg-laying and of juvenile hatching were 435 and 692 day-degrees for M. hapla and 378 and 566 day-degrees for M. javanica, respectively. VRAIN et al.(12) and MILNE \& DUPLESSIS (5) also reported the temperature (heat unit) required for $M$. hapla and $M$. javanica to lay eggs after penetration to host plant in the field. When converted to day-degrees, the heat values were 450 and 375 day-degrees for $M$. hapla and $M$. javanica, respectively, indicating that the total temperatures required by the two nematodes for development on transformed roots were almost comparable to those on ordinary plants in the 
field.

Among the three main root-knot nematodes found in Japan, M. hapla shows the northernmost distribution while $M$. javanica, and $M$. incognita are distributed more southerly in that order $(3,8)$. By using transformed roots of oriental-melon (Cucumis melo L.) under the same condition as the present investigation, the developmental zero degree of $M$. incognita was estimated to be $10.9^{\circ} \mathrm{C}$, and 435 day-degrees for the total effective temperature for the completion of one generation (1). Considering these values in combination with the results from the present study, the developmental zero degrees of a nematode is likely to decrease and the total effective temperature for the completion of one generation to increase, when the latitude of the distributional range increases and the average temperature decreases.

The distribution of $M$. javanica in Japan, which occurs at a higher latitude than that of $M$. incognita, does not coincide with the observations reported from foreign countries(10). Moreover, since the enzyme phenotypes of $M$. javanica from Japan were not comparable to those of $M$. javanica (7) from overseas, further studies should be carried out to determine whether these $M$. javanica are physiologically/biochemically identical to each other.

THOMASON \& LEAR(11) reported that in $M$. hapla the number of egg masses decreased at higher temperatures than $30^{\circ} \mathrm{C}$. This phenomenon may be ascribed to the fact that smaller numbers of mature females and eggs were obtained at $30^{\circ} \mathrm{C}$ in the present study. Meloidogyne javanica, on the other hand, did not show any changes in these parameters at temperatures ranging from 20 to $30^{\circ} \mathrm{C}$.

Effect of temperature on the morphology of the 2nd-stage juveniles showed a similar tendency both for $M$. hapla and M. javanica; the body length, a-value, and tail length decreased with increasing temperature. Since the decrease in the a-value was not accompanied by any change in maximum body width, the increase in temperature supposedly affected only the body length which decreased.

Our study, in addition to the attempts to culture $M$. incognita on transformed roots, demonstrated that sterile culture of $M$. hapla and $M$. javanica could be achieved on hairy root system. This method will enable us to study physiology, biochemistry, or behavioral ecology of plant nematodes.

\section{ACKNOWLEDGEMENT}

We express our sincere thanks to Mr. Yasuomi OHSHIMA of the National Agriculture Research Center for his valuable comments on this manuscript.

\section{LITERATURE CITED}

1) Adachi, H., Narabu T. \& Momota Y. (1992) Culture of Meloidogyne incognita on oriental-melon roots genetically transformed by Agrobacterium rhizogenes. Jpn. J. Appl. Entomol. Zool. 36, 225230. (In Japanese with English summary)

2 ) BECARD, G. \& ForTin, J. A. (1988) Early events of vesicular-arbuscular mycorrhiza formation on Ri T-DNA transformed roots. New Phytol. 108, 211-218.

3 ) Goto, A. (1977) Distribution of main plant-parasitic nematodes in Japan. Kongetu no Nouyaku 21 (12), 12-16. (In Japanese)

4 ) Lloyd, G. \& McCown, B. (1980) Commercially-feasible micropropagation of mountain laurel, Kalmia latifolia, by use of shoot-tip culture. Int. Plant Propagators' Soc. Combined Proc. for 1980, 
421-427.

5 ) Milne, D. L. \& Duplessis, D. P. (1964) Development of Meloidogyne javanica (Treub) Chitwood on tobacco under fluctuating soil temperatures. S. Afr. Agric. Sci. 7, 673-680.

6 ) NARABU T. \& MOмOTA Y. (1992) Occurrence and analysis of resistance breaking populations of Meloidogyne incognita on tomato cultivars. Proc. Kanto-Tosan Pl. Protec. Soc. 39, 297-299. (In Japanese with English summary)

7 ) Narabu T., Namba S., Yamashita S. \& Tsuchizaki T. (1989) Use of enzyme phenotypes for identification of three Meloidogyne species in Japan. Jpn. J. Nematol. 19, 46-51. (In Japanese with English summary)

8 ) Ohashi, Y., IshiI, K. \& MAEdA, H. (1972) Distribution of root-knot nematodes at tobacco fields in Kanto-Kousinetu area. Hatabako Kenkyu 60, 80-84. (In Japanese)

9 ) Tanaka, N., Hayakawa, M., Mano, Y., Ohkawa, H. \& Matsui, C. (1985) Infection of turnip and radish storage roots with Agrobacterium rhizogenes. Plant Cell Rep. 4: 74-77.

10) Taylor, A. L. \& Sasser, J. N. (1978) Biology, Identification and Control of Root-Knot Nematodes (Meloidogyne species). N. C. State Univ., Raleigh, 111 pp.

11) Thomason, I. J. \& Lear, B. (1961) Rate of reproduction of Meloidogyne spp. as influenced by soil temperature. Phytopathology 51: 520-524.

12) Verdejo, S., Jaffee, B. A. \& MAnkau, R. (1988) Reproduction of Meloidogyne javanica on plant roots genetically transformed by Agrobacterium rhizogenes. J. Nematol. 10: 599-604.

13) Vrain, T. C., Barker, K. R. \& Holtzman, G. I. (1978) Influence of low temperature on rate of development of Meloidogyne incognita and M. hapla larvae. J. Nematol. 10, 166-171.

Accepted for publication: April 20, 1993

\title{
和文摘要
}

\section{数種毛状根でのキタネコブセンチュウおよび ジャワネコブセンチュウの培養}

\author{
安達宏・奈良部 孝・百田 洋二
}

Agrobacterium rhizogenes 菌により誘導された数種毛状根を用いてキタネコブセンチュウおよび ジャワネコブセンチュウの増殖を比較した。キタネコブセンチュウはトマト（品種：桃太郎および ファーストモア)、ジャワネコブセンチュウはトマト (品種：ファーストモア）抽びナスで最も高い 増殖が認められた。トマト（品種：ファーストモア）毛状根を用いた培養条件下での 2 種線虫の発育 零点、産卵開始までの有効積算温度および一世代完了までの有効積算温度は、キタネコブセンチュウ が6. $8^{\circ} \mathrm{C} 、 435$ 日度および692日度、ジャワネコブセンチュウが $10.1^{\circ} \mathrm{C} 、 378$ 日度および566日度であっ た。第 2 期幼虫の体長、体長／最大体幅および尾長は温度の上昇とともに減少した。 